\title{
Mortality of elderly patients in Ontario after hospital admission for chronic obstructive pulmonary disease
}

\author{
Jason X Nie BSc ${ }^{1}$, Li Wang MD MSc ${ }^{1}$, Ross EG Upshur MD MA MSc CCFP FRCPC ${ }^{1-5}$
}

\begin{abstract}
JX Nie, Li Wang, REG Upshur. Mortality of elderly patients in Ontario after hospital admission for chronic obstructive pulmonary disease. Can Respir J 2007;14(8):485-489.
\end{abstract}

BACKGROUND: Chronic obstructive pulmonary disease (COPD) is associated with significant mortality. It is currently the fourth leading cause of death in Canada and the world.

OBJECTIVES: To describe the mortality of elderly patients in Ontario after hospital admission for COPD.

METHODS: A retrospective cohort study was conducted using the Discharge Abstract Database from the Canadian Institute for Health Information. Patients aged 65 years and older who were admitted to hospital between 2001 and 2004 with primary discharge diagnoses labelled with International Classification of Diseases, Ninth Revision codes 491, 492 and 496 were included in the study.

RESULTS: Mortality rates were $8.81,12.10,14.53$ and 27.72 per 100 COPD hospital admissions at 30, 60, 90 and 365 days after hospital discharge, respectively. Mortality also increased with age, and men had higher rates than women. No significant differences in mortality rates were found between different socioeconomic groups $(\mathrm{P}>0.05)$. Patients with shared care of a family physician or general practitioner and a specialist had significantly lower mortality rates than the overall rate $(\mathrm{P}<0.05)$, and their rates were approximately one-half the rate of patients with only one physician.

CONCLUSIONS: Hospitalization with COPD is associated with significant mortality. Patients who were cared for by both a family physician or general practitioner and a specialist had significantly lower mortality rates than those cared for by only one physician, suggesting that continuous and coordinated care results in better survival.

Key Words: Chronic obstructive pulmonary disease; Epidemiology; Mortality; Physician type; Socioeconomic status

$\mathrm{C}$ hronic obstructive pulmonary disease (COPD) is associated with significant morbidity and mortality. In 2002, the World Health Organization ranked COPD, alongside HIV/AIDS, as the fourth leading cause of death globally, trailing only ischemic heart disease, cerebrovascular disease and lower respiratory infections (1). COPD is also ranked as the fourth leading cause of death in the United States (US), Europe and Canada (2,3). In 1997, 4\% of all deaths in Canada were attributed to COPD (3). However, even this may be an underestimation of COPD mortality, because COPD may not always be listed as the primary cause of death on the death certificate, but rather as an underlying cause (4).

More alarmingly, COPD is one of the few major causes of death that continue to rise in the US and the world $(5,6)$. It is estimated that by the year 2020, COPD will be the third leading

\section{Mortalité chez des patients âgés en Ontario, hospitalisés pour une bronchopneumopathie chronique obstructive}

CONTEXTE : La bronchopneumopathie chronique obstructive (BPCO) est associée à une forte mortalité; en fait, elle est la quatrième cause de mortalité au Canada et dans le monde, aujourd'hui.

BUT : Létude avait pour but de caractériser la mortalité chez des patients âgés en Ontario, hospitalisés pour une BPCO.

MÉTHODE : Nous avons entrepris une étude de cohortes, rétrospective à partir de la Base de données sur les congés des patients, obtenue de l'Institut canadien d'information sur la santé. Ont été inclus dans l'étude des patients âgés de 65 ans et plus, hospitalisés entre 2001 et 2004 pour des affections dont le diagnostic principal, indiqué sur le formulaire de congé, portaient les codes 491, 492 ou 496, selon la Classification internationale des maladies, $9^{\mathrm{e}}$ révision.

RÉSULTATS : Les taux de mortalité pour 100 hospitalisations motivées par une BPCO étaient respectivement de 8,81;12,10; 14,53 et 27,72 au bout de 30, 60, 90 et 365 jours après le congé de l'hôpital. La mortalité augmentait également avec l'âge et elle était supérieure chez les hommes par rapport aux femmes. Nous n'avons pas noté d'écart significatif de taux de mortalité entre les différents groupes socio-économiques $(\mathrm{P}>0,05)$. Cependant, les patients suivis à la fois par un médecin de famille ou un omnipraticien et un spécialiste ont connu des taux de mortalité significativement plus faibles que l'ensemble des patients $(\mathrm{P}<0,05)$, et leurs taux étaient à peu près la moitié de ceux enregistrés chez les patients suivis par un seul médecin.

CONCLUSIONS : L'hospitalisation pour cause de BPCO est associée à une mortalité élevée. Les patients suivis à la fois par un médecin de famille ou un omnipraticien et un spécialiste ont connu des taux de mortalité significativement plus faibles que les patients suivis par un seul médecin, ce qui porte à croire que des soins continus et coordonnés favorisent une survie prolongée.

${ }^{1}$ Primary Care Research Unit, Sunnybrook Health Sciences Centre; ${ }^{2}$ Department of Family and Community Medicine; ${ }^{3}$ Department of Public Health Sciences, University of Toronto; ${ }^{4}$ Institute for Clinical Evaluative Sciences; ${ }^{5}$ University of Toronto Joint Centre for Bioethics, Toronto, Ontario Correspondence: Dr Ross EG Upshur, Primary Care Research Unit, Sunnybrook Health Sciences Centre, 2075 Bayview Avenue, \#E-349,

Toronto, Ontario M4N 3M5. Telephone 416-480-6100 ext 4753, fax 416-480-4536, e-mail ross.upshur@sunnybrook.ca 
TABLE 1

Sex- and comorbidity-adjusted mortality rates per 100 chronic obstructive pulmonary disease admissions in those aged 65 years and older in Ontario by age group, 2000 to 2004

\begin{tabular}{|c|c|c|c|c|c|c|c|c|c|}
\hline \multirow[b]{2}{*}{$\begin{array}{l}\text { Age group } \\
\text { (years) }\end{array}$} & \multirow[b]{2}{*}{$\mathbf{n}$} & \multicolumn{2}{|c|}{ 30-day mortality } & \multicolumn{2}{|c|}{60 -day mortality } & \multicolumn{2}{|c|}{ 90-day mortality } & \multicolumn{2}{|c|}{ 365-day mortality } \\
\hline & & $\begin{array}{l}\text { Crude } \\
\text { rate }\end{array}$ & $\begin{array}{l}\text { Adjusted rate } \\
\qquad(95 \% \mathrm{Cl})\end{array}$ & $\begin{array}{l}\text { Crude } \\
\text { rate }\end{array}$ & $\begin{array}{l}\text { Adjusted rate } \\
\qquad(95 \% \mathrm{Cl})\end{array}$ & $\begin{array}{l}\text { Crude } \\
\text { rate }\end{array}$ & $\begin{array}{l}\text { Adjusted rate } \\
\qquad(95 \% \mathrm{Cl})\end{array}$ & $\begin{array}{l}\text { Crude } \\
\text { rate }\end{array}$ & $\begin{array}{l}\text { Adjusted rate } \\
\qquad(95 \% \mathrm{Cl})\end{array}$ \\
\hline $65-74$ & 12,380 & 5.75 & $6.13(5.62-6.64)^{*}$ & 7.92 & $8.4(7.81-8.98)^{*}$ & 9.94 & $10.49(9.87-11.12)^{*}$ & 20.55 & $21.36(20.57-22.15)^{\star}$ \\
\hline $75-84$ & 14,544 & 9.17 & $9.08(8.63-9.53)$ & 12.90 & $12.77(12.26-13.29)^{\dagger}$ & 15.42 & $15.28(14.73-15.84)^{\dagger}$ & 29.35 & $29.13(28.42-29.83)^{\dagger}$ \\
\hline 85 and older & 5257 & 15.05 & $13.43(12.72-14.13)^{\dagger}$ & 19.73 & $17.79(16.98-18.60)^{\dagger}$ & 22.85 & $20.8(19.92-21.67)^{\dagger}$ & 40.08 & $37.52(36.40-38.63)^{\dagger}$ \\
\hline Overall & 32,181 & 8.81 & & 12.10 & & 14.53 & & 27.72 & \\
\hline
\end{tabular}

*Significantly lower than the overall rate; ${ }^{\dagger}$ Significantly higher than the overall rate

by medical care, including pulmonary rehabilitation. Although there have been several previous studies examining the type of physician care - generalist versus specialist - and COPD mortality, no studies, to our knowledge, have looked at the COPD mortality of patients who are cared for by both types of physicians.

COPD symptoms are not usually exhibited until the age of 55 years, and because it progresses slowly over a period of years, mortality often does not occur until 65 years of age or older. The elderly population of Ontario has been increasing, from a $40 \%$ rise in the population 80 years of age and older between 1991 and 2001, to an estimated 50\% increase between 2001 and 2011 (14). It is therefore important to examine the trends of COPD mortality to prepare the health care system for its burdens. Using population-based data for the province of Ontario over a four-year period (2000 to 2004), the objective of the present study was to investigate the mortality rates of elderly Ontario patients after hospital admission for COPD by age group, sex, SES and physician type.

\section{Study cohort}

\section{METHODS}

This was a retrospective cohort study. The study cohort consisted of patients in Ontario identified as having COPD from the Canadian Institute for Health Information Discharge Abstract Database from April 1, 2000, to March 31, 2004. The quality of coding in Canadian Institute for Health Information for COPD has been assessed and validated, and has been found to be reliable (15). Patients with a primary discharge diagnosis of COPD were included in the study. International Classification of Diseases, Ninth Revision codes 491 (chronic bronchitis), 492 (emphysema) and 496 (chronic airway obstruction not elsewhere classified) were used to identify COPD patients. Patients were excluded if they were younger than 65 years or older than 110 years, if they had invalid health card numbers, if they died in hospital or if they were transferred from one acute care hospital to another. The index hospital admission and discharge dates were defined as the dates of the first admission and discharge from hospital during the study period, respectively. Mortality information was obtained from the Registered Persons Database, which was used to determine the 30-day, 60-day, 90-day and one-year mortality rates from the date of the index discharge date for patients in this cohort.

\section{SES}

For each person in the study cohort, SES quintiles were calculated using a person's postal code, available in the Registered Persons Database. Statistics Canada has estimated neighbourhood level socioeconomic gradients (based on income) (16). Each adult's postal code was linked to the appropriate Statistics Canada SES quintile gradient, with quintile 1 having the lowest income and quintile 5 the highest.

\section{Physician visits}

Information regarding health service utilization was obtained from the Ontario Health Insurance Plan database, which contains billing information on all 'fee for service' outpatient visits. This database was used to determine the occurrence of outpatient physician visits for COPD within one year before the index hospitalization. The Corporate Provider Database was used to track each physician's specialty.

\section{Statistical analysis}

Analysis of the data involved the use of logistic regression to adjust for age, sex and Deyo-Charlson comorbidity indexes. In addition, $\chi^{2}$ testing was performed to assess for statistically significant differences in mortality rates. All statistics were analyzed using SAS software, version 9.1 (SAS Inc, USA). A probability level of 0.05 was set for statistical significance.

\section{RESULTS}

The overall rates of mortality were 8.81 per 100 COPD admissions 30 days after discharge, 12.10 after 60 days, 14.53 after 90 days and 27.72 after 365 days.

Table 1 describes the mortality rates per 100 COPD admissions for patients aged 65 years and older in Ontario by age group from 2000 to 2004 . COPD mortality in the 75 - to 84-year-old age group (not including mortality within 30 days of discharge) and in the 85-year-old and older age group was significantly higher than the overall rate. Mortality rates in the 65- to 74-year-old age group were significantly lower than the overall rate for all durations after hospital discharge. The highest rate of mortality was seen in the 85-year-old and older age group 365 days after discharge, while the lowest rate was the 30-day mortality of those aged 65 to 74 years. When the mortality rate was separated by sex (Table 2), men had a higher mortality rate in all groups than women, statistically higher than the overall rate.

COPD mortality rates by SES (Table 3) showed no significant difference among the five SES groups, except for those in the fourth quintile of SES gradient 30 and 60 days after discharge, who showed statistically higher rates than the overall rate.

Mortality rates by physician type (Table 4) showed that patients who had shared care with a family physician or general practitioner $(\mathrm{FP} / \mathrm{GP})$ and COPD specialist had a significantly lower mortality rate than the overall rate, while those with an 
TABLE 2

Age- and comorbidity-adjusted mortality rates per 100 chronic obstructive pulmonary disease admissions in those aged 65 years and older in Ontario by sex, 2000 to 2004

\begin{tabular}{|c|c|c|c|c|c|c|c|c|c|}
\hline \multirow[b]{2}{*}{ Sex } & \multirow[b]{2}{*}{$\mathbf{n}$} & \multicolumn{2}{|c|}{ 30-day mortality } & \multicolumn{2}{|c|}{ 60-day mortality } & \multicolumn{2}{|c|}{ 90-day mortality } & \multicolumn{2}{|c|}{ 365-day mortality } \\
\hline & & $\begin{array}{l}\text { Crude } \\
\text { rate }\end{array}$ & $\begin{array}{c}\text { Adjusted rate } \\
(95 \% \mathrm{Cl})\end{array}$ & $\begin{array}{l}\text { Crude } \\
\text { rate }\end{array}$ & $\begin{array}{c}\text { Adjusted rate } \\
(95 \% \mathrm{Cl})\end{array}$ & $\begin{array}{l}\text { Crude } \\
\text { rate }\end{array}$ & $\begin{array}{c}\text { Adjusted rate } \\
(95 \% \mathrm{Cl})\end{array}$ & $\begin{array}{l}\text { Crude } \\
\text { rate }\end{array}$ & $\begin{array}{c}\text { Adjusted rate } \\
(95 \% \mathrm{Cl})\end{array}$ \\
\hline Female & 15,794 & 7.98 & $8.19(7.75-8.63)^{*}$ & 10.74 & $11.02(10.51-11.53)^{*}$ & 12.97 & $13.30(12.75-13.84)^{\star}$ & 24.85 & $25.35(24.66-26.30)^{*}$ \\
\hline Male & 16,387 & 9.61 & $9.38(8.96-9.80)^{\dagger}$ & 13.40 & $13.08(12.60-13.57)^{\dagger}$ & 16.03 & $15.66(15.14-16.17)^{\dagger}$ & 30.48 & $29.91(29.26-30.56)^{\dagger}$ \\
\hline Overall & 32,181 & 8.81 & & 12.10 & & 14.53 & & 27.72 & \\
\hline
\end{tabular}

*Significantly lower than the overall rate; ${ }^{\dagger}$ Significantly higher than the overall rate

TABLE 3

Age-, sex- and comorbidity-adjusted mortality rates per 100 chronic obstructive pulmonary disease admissions in those aged 65 years and older in Ontario by socioeconomic status (SES), 2000 to 2004 (missing SES excluded)

\begin{tabular}{|c|c|c|c|c|c|c|c|c|c|}
\hline \multirow[b]{2}{*}{$\begin{array}{l}\text { SES } \\
\text { quintile (Q) }\end{array}$} & \multirow[b]{2}{*}{$\mathbf{n}$} & \multicolumn{2}{|c|}{ 30-day mortality } & \multicolumn{2}{|c|}{ 60-day mortality } & \multicolumn{2}{|c|}{ 90-day mortality } & \multicolumn{2}{|c|}{ 365-day mortality } \\
\hline & & $\begin{array}{l}\text { Crude } \\
\text { rate }\end{array}$ & $\begin{array}{l}\text { Adjusted rate } \\
(95 \% \mathrm{Cl})\end{array}$ & $\begin{array}{l}\text { Crude } \\
\text { rate }\end{array}$ & $\begin{array}{l}\text { Adjusted rate } \\
(95 \% \mathrm{Cl})\end{array}$ & $\begin{array}{l}\text { Crude } \\
\text { rate }\end{array}$ & $\begin{array}{l}\text { Adjusted rate } \\
(95 \% \mathrm{Cl})\end{array}$ & $\begin{array}{l}\text { Crude } \\
\text { rate }\end{array}$ & $\begin{array}{c}\text { Adjusted rate } \\
(95 \% \mathrm{Cl})\end{array}$ \\
\hline Q1 & 8507 & 8.25 & $8.47(7.86-9.07)$ & 11.20 & $11.50(10.81-12.19)$ & 13.44 & $13.78(13.04-14.52)^{*}$ & 26.38 & $26.89(25.96-27.82)$ \\
\hline Q2 & 7267 & 8.59 & $8.60(7.96-9.24)$ & 12.21 & $12.21(11.48-12.94)$ & 14.78 & $14.78(13.99-15.57)$ & 27.74 & $27.75(26.76-28.75)$ \\
\hline Q3 & 5888 & 8.63 & $8.52(7.81-9.22)$ & 11.92 & $11.78(10.98-12.59)$ & 14.42 & $14.26(13.39-15.13)$ & 27.73 & $27.51(26.42-28.61)$ \\
\hline Q4 & 4963 & 9.89 & $9.89(9.02-10.57)^{\dagger}$ & 13.26 & $13.11(12.23-13.99)^{\dagger}$ & 15.60 & $15.44(14.49-16.39)$ & 28.75 & $28.51(27.32-29.71)$ \\
\hline Q5 & 4294 & 9.13 & $9.02(8.19-9.85)$ & 12.55 & $12.40(11.45-13.34)$ & 15.32 & $15.13(14.11-16.15)$ & 28.44 & $28.14(26.85-29.42)$ \\
\hline Overall & 30,919 & 8.81 & & 12.10 & & 14.53 & & 27.72 & \\
\hline
\end{tabular}

*Significantly lower than the overall rate; 'Significantly higher than the overall rate

\section{TABLE 4}

Age-, sex- and comorbidity-adjusted mortality rates per 100 chronic obstructive pulmonary disease (COPD) admissions in those aged 65 years and older in Ontario by physician type, 2000 to 2004

\begin{tabular}{|c|c|c|c|c|c|c|c|c|c|}
\hline \multirow{2}{*}{$\begin{array}{l}\text { Physician visited } \\
\text { within one year } \\
\text { before admission }\end{array}$} & \multirow[b]{2}{*}{$\mathbf{n}$} & \multicolumn{2}{|c|}{ 30-day mortality } & \multicolumn{2}{|c|}{60 -day mortality } & \multicolumn{2}{|c|}{ 90-day mortality } & \multicolumn{2}{|c|}{ 365-day mortality } \\
\hline & & $\begin{array}{l}\text { Crude } \\
\text { rate }\end{array}$ & $\begin{array}{c}\text { Adjusted rate } \\
(95 \% \mathrm{CI})\end{array}$ & $\begin{array}{l}\text { Crude } \\
\text { rate }\end{array}$ & $\begin{array}{c}\text { Adjusted rate } \\
(95 \% \mathrm{Cl})\end{array}$ & $\begin{array}{l}\text { Crude } \\
\text { rate }\end{array}$ & $\begin{array}{c}\text { Adjusted rate } \\
(95 \% \mathrm{Cl})\end{array}$ & $\begin{array}{l}\text { Crude } \\
\text { rate }\end{array}$ & $\begin{array}{c}\text { Adjusted rate } \\
(95 \% \mathrm{Cl})\end{array}$ \\
\hline $\begin{array}{l}\text { FP/GP with } \\
\text { COPD specialist* }\end{array}$ & 13,311 & 6.47 & $6.99(6.50-7.49)^{\dagger}$ & 9.41 & $10.15(9.58-10.72)^{\dagger}$ & 11.72 & $12.59(11.98-13.20)^{\dagger}$ & 24.80 & $26.23(25.47-27.00)^{\dagger}$ \\
\hline FP/GP only & 6122 & 13.03 & $11.92(11.26-12.58)^{\ddagger}$ & 17.13 & $15.67(14.91-16.42)^{\ddagger}$ & 20.14 & $18.48(17.67-19.29)^{\ddagger}$ & 36.26 & $33.86(32.83-34.88)^{\ddagger}$ \\
\hline COPD & 572 & 14.34 & $12.44(10.35-14.52)^{\ddagger}$ & 19.58 & $16.97(14.60-19.34)^{\ddagger}$ & 23.60 & $20.49(17.94-23.03)^{\ddagger}$ & 35.84 & $32.14(28.91-35.37)^{\ddagger}$ \\
\hline
\end{tabular}

specialist* only

$\begin{array}{lllll}\text { Overall } & 20,005 & 8.81 & 12.10 & 14.53\end{array}$

*COPD specialists included respirologists, internists and geriatricians; ${ }^{\dagger}$ Significantly lower than the overall rate; $¥$ Significantly higher than the overall rate. FP Family physician; GP General practitioner

FP/GP or a COPD specialist only had a significantly higher mortality rate. With the exception of mortality 365 days after hospital discharge, patients with shared care had mortality rates that were approximately one-half those of patients who had only one physician; mortality rates were higher for those who were cared for by a COPD specialist only than for those who saw an FP/GP only.

\section{DISCUSSION}

The outcomes of COPD mortality by age group and sex in the present study are consistent with previous studies (2-4,8$10,12)$. Disease progression in the oldest age group may be attributed to an increased likelihood of comorbid illness, a compromised immune system and decreased lung function associated with age, leading to higher rates of mortality $(7,17)$. Our results show that mortality rates are still higher for men than women. However, there is evidence that the rate of mortality in women with COPD has been increasing, while the rates in men have slightly decreased, reflecting the current smoking trends $(2,4,10,18,19)$. For example, during the years
1968 to 1999 in the US, the COPD death rate for women increased by $382 \%$, compared with only a $27 \%$ increase in men during the same period (18). It is therefore very likely that this sex difference will disappear in the near future.

The present study shows that SES does not affect COPD mortality, despite evidence that COPD mortality increases as one's SES decreases. This may be evidence of a successful universal health care system in Canada. A previous study of the relation between socioeconomic class and chronic pulmonary disease in the Hamilton-Burlington area of southern Ontario found that subjects with chronic pulmonary disease had a lower mean household income than those without the disease, which can be attributed to the inverse relationship between smoking prevalence and income (20). However, the effect of SES on mortality rates of chronic pulmonary disease patients was not discussed. Other studies on the effect of social position on mortality from COPD in Denmark revealed that a lower income was strongly associated with respiratory mortality in both sexes $(21,22)$. Adjusting for smoking, factors associated with a lower income that put individuals at higher risk include exposure to 
environmental factors such as outdoor and indoor air pollution, occupational exposures on respiratory health and being more likely to live in a house of poor quality located in environmentally hazardous areas (20-22).

In our results, patients cared for by specialists had a slightly higher mortality rate than those cared by an FP/GP. A possible explanation may be that patients who are cared for by specialists only may have more advanced disease and comorbid conditions. There is conflicting evidence regarding physician type and COPD mortality in the literature. Some studies have linked specialists to better outcomes in COPD patients, such as fewer number of visits, being more likely to receive pharmacological and nonpharmacological treatments, and being more likely to perform correct inhalation manoeuvres (23).

In contrast, other studies have argued that generalists provide equally good and less expensive care as specialists. A study of the difference in survival for patients hospitalized with exacerbations of severe COPD showed that patients with respirologists as their attending physicians did not have a higher survival rate than those with generalists as attending physicians (24). The authors argued that this was because patients were likely to have received similar treatments due to the uniform practice patterns of generalists and respirologists; because of extensive comanagement of generalist patients by respirology consultants; and because no specific treatments have been demonstrated to improve survival in seriously ill patients hospitalized for acute exacerbations of COPD, due to limited COPD treatments. Similar results were obtained in another study, which found no differences in outcomes for ambulatory patients with COPD between care provided by specialists and care provided by generalists (25).

We are not aware of any previous studies that compared the rates of mortality of COPD patients who had either specialist care only or FP/GP care only with those who had both. From our results, it is evident that patients who are cared for by both a specialist and an FP/GP have a significantly lower mortality rate than those cared for by only one physician. This suggests that the continuity and coordination of care between FPs/GPs and specialists result in better survival for COPD patients. The higher mortality rate among those cared for only by an FP/GP indicates a pressing need for targeted continuing education and perhaps the introduction of a standard of shared care for COPD patients.

This study has a few possible limitations. While administrative health data files accurately record physician service claims of COPD, they do not test the validity of those diagnoses. A further limitation of this study is the measure used for SES, specifically the use of median neighbourhood income to determine income data. Although the application of area-level information to individuals may not provide precise income levels, it has been shown that there is a strong correlation between ecological measures of income and an individual's income. In the absence of individual level data, the use of proxy measures is warranted (26-28).

\section{CONCLUSIONS}

In this population-based, retrospective cohort study, significant mortality was associated with elderly patients in Ontario who were admitted to hospital for COPD. Mortality increased over time after hospital discharge. Male sex and older age significantly increased mortality. However, SES was not a factor in increased risk of death subsequent to hospital admission for
COPD. Patients who were cared for by both a generalist and a specialist had significantly lower mortality rates than those cared for by one physician only.

Although the present study was mainly descriptive and did not investigate all of the factors influencing mortality rates of elderly COPD patients in Ontario, these results do add to our understanding of COPD mortality in Ontario. The findings can further contribute to research on more specific factors attributable to COPD mortality, as well as better management strategies for this disease.

ACKNOWLEDGEMENTS: The authors acknowledge Davika Ram for her help with the review of the literature and Shari Gruman for formatting this manuscript.

FUNDING: This study was funded by the Primary Health Care Transition Fund, Ontario Ministry of Health and Long-Term Care and Health Canada. Ross Upshur is supported by the Canada Research Chair in Primary Care Research, as well as a Research Scholar Award from the Department of Family and Community Medicine, University of Toronto, Toronto, Ontario.

\section{REFERENCES}

1. Colin D. Mathers, Dejan Loncar. Evidence and Information for Policy, World Health Organization, October 2005.

Updated projections of global mortality and burden of disease, 2002-2030: Data sources, methods and results.

<http://www.who.int/healthinfo/statistics/bodprojectionspaper.pdf> (Version current at October 16, 2007).

2. Devereux G. ABC of chronic obstructive pulmonary disease. Definition, epidemiology, and risk factors. BMJ 2006;332:1142-4.

3. Statistics Canada. Selected leading causes of death, by sex. <http://www40.statcan.ca/101/cst01/health36.htm?sdi= leading\%20causes\%20death> (Version current at October 16, 2007).

4. Canadian Institute for Health Information, Canadian Lung Association, Health Canada, Statistics Canada. Respiratory disease in Canada, September 2001. < http://www.phac-aspc.gc.ca/publicat/ rdc-mrc01/index.html> (Version current at October 16, 2007).

5. Celli BR. Predicting mortality in chronic obstructive pulmonary disease: Chasing the "Holy Grail". Am J Respir Crit Care Med 2006;173:1298-9.

6. Mannino DM. Epidemiology and global impact of chronic obstructive pulmonary disease. Semin Respir Crit Care Med 2005;26:204-10.

7. Gudmundsson G, Gislason T, Lindberg E, et al. Mortality in COPD patients discharged from hospital: The role of treatment and co-morbidity. Respir Res 2006;7:109.

8. Hurd S. The impact of COPD on lung health worldwide: Epidemiology and incidence. Chest 2000;117(Suppl 2):1S-4S.

9. The Lung Association. What is chronic obstructive pulmonary disease? < http://www.on.lung.ca/Lung-Health/COPD.php> (Version current at October 19, 2007).

10. Chen Y, Stewart P, Dales R, Johansen H, Bryan S, Taylor G. Changing age-pattern of hospitalisation risk of chronic obstructive pulmonary disease in men and women in Canada. Age Ageing 2005;34:373-7.

11. Ezzati M, Lopez AD. Estimates of global mortality attributable to smoking in 2000. Lancet 2003;362:847-52.

12. Meyer PA, Mannino DM, Redd SC, Olson DR. Characteristics of adults dying with COPD. Chest 2002;122:2003-8.

13. World Health Organization. COPD: Causes. <http://www.who.int/respiratory/copd/causes/en/print.html> (Version current at October 16, 2007).

14. Statistics Canada. 2001 Census Analysis Series - Profile of the Canadian population by age and sex: Canada ages. Catalogue \#6F0030XIE2001002, page 21.

15. Rawson NS, Malcolm E. Validity of the recording of ischaemic heart disease and chronic obstructive pulmonary disease in the Saskatchewan health care datafiles. Stat Med 1995;14:2627-43. 
16. Statistics Canada. Postal Code Conversion File (PCCF), Census 2001. $<$ http://www.statcan.ca/bsolc/english/bsolc?catno=92F0153XCE $>$ (Version current at October 22, 2007).

17. Kim S, Clark S, Camargo C. Mortality after an emergency department visit for exacerbation of chronic obstructive pulmonary disease. COPD 2006;3:75-81.

18. Weir E. COPD death rates: Projecting a female trajectory. CMAJ 2004;170:334.

19. Kazerouni N, Alverson CJ, Redd SC, Mott JA, Mannino DM. Sex differences in COPD and lung cancer mortality trends United States, 1968-1999. J Womens Health (Larchmt) 2004;13:17-23.

20. Finkelstein MM, Jerrett M, DeLuca P, et al. Relation between income, air pollution and mortality: A cohort study. CMAJ 2003; 169:397-402.

21. Prescott E, Lange P, Vestbo J. Socioeconomic status, lung function and admission to hospital for COPD: Results from the Copenhagen City Heart Study. Eur Respir J 1999;13:1109-14.

22. Prescott E, Godtfredsen N, Vestbo J, Osler M. Social position and mortality from respiratory diseases in males and females. Eur Respir J 2003;21:821-6.
23. Garcia-Aymerich J, Escarrabill J, Marrades RM, et al. Differences in COPD care among doctors who control the disease: General practitioner vs. pneumologist. Respir Med 2006;100:332-9.

24. Regueiro CR, Hamel MB, Davis RB, Desbiens N, Connors AF Jr, Phillips RS. A comparison of generalist and pulmonologist care for patients hospitalized with severe chronic obstructive pulmonary disease: Resource intensity, hospital costs, and survival. SUPPORT Investigators. Study to Understand Prognoses and Preferences for Outcomes and Risks of Treatment. Am J Med 1998;105:366-72.

25. Strauss MJ, Conrad D, LoGerfo JP, Hudson LD, Bergner M. Cost and outcome of care for patients with chronic obstructive lung disease. Analysis by physician specialty. Med Care 1986;24:915-24.

26. Mustard CA, Derksen S, Berthelot JM, Wolfson M. Assessing ecologic proxies for household income: A comparison of household and neighbourhood level income measures in the study of population health status. Health Place 1999;5:157-71.

27. Roos N P, Mustard CA. Variation in health and health care use by socioeconomic status in Winnipeg, Canada: Does the system work well? Yes and no. Milbank Q 1997;75:89-111.

28. Krieger N. Overcoming the absence of socioeconomic data in medical records: Validation and application of a census-based methodology. Am J Public Health 1992;82:703-10. 


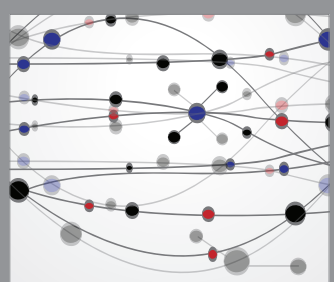

The Scientific World Journal
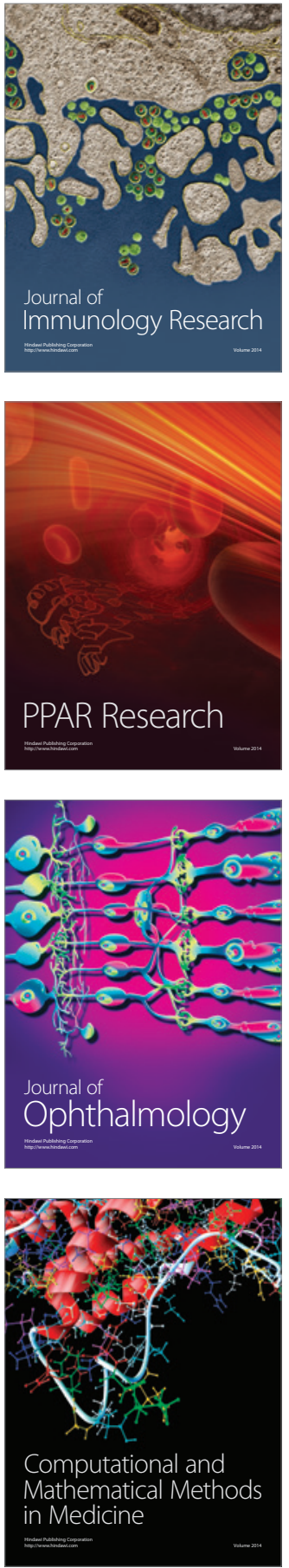

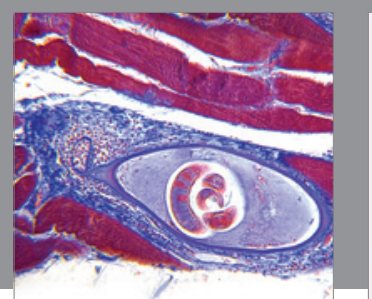

Gastroenterology Research and Practice

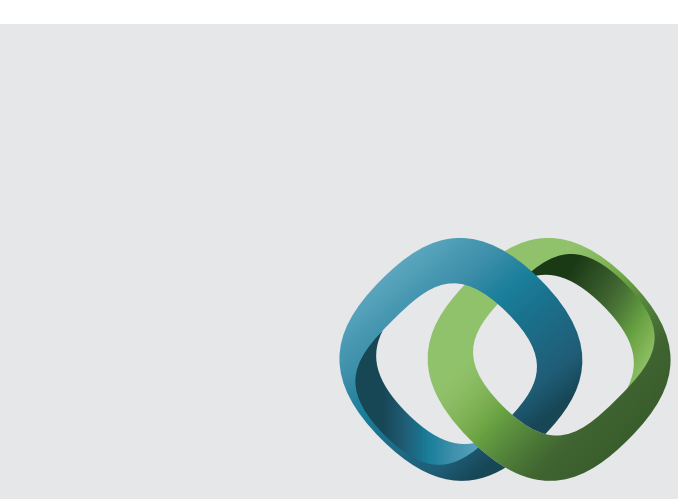

\section{Hindawi}

Submit your manuscripts at

http://www.hindawi.com
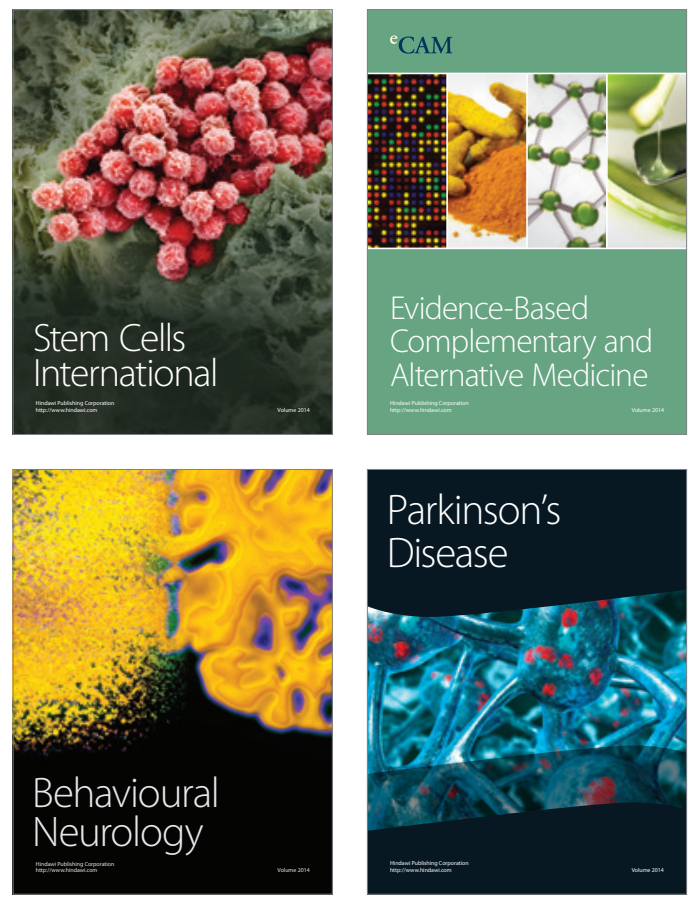
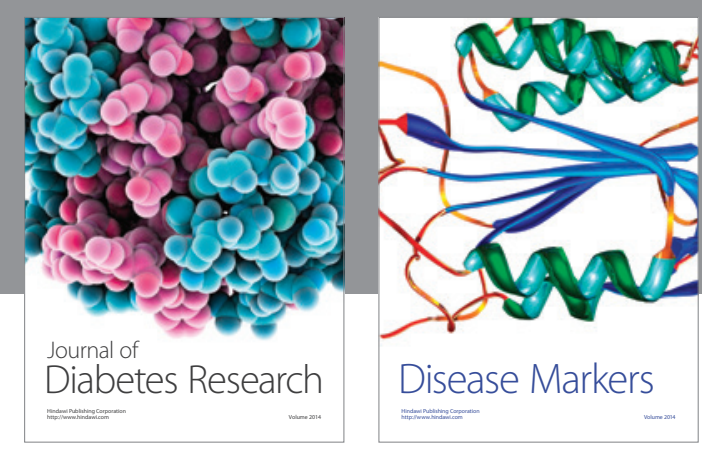

Disease Markers
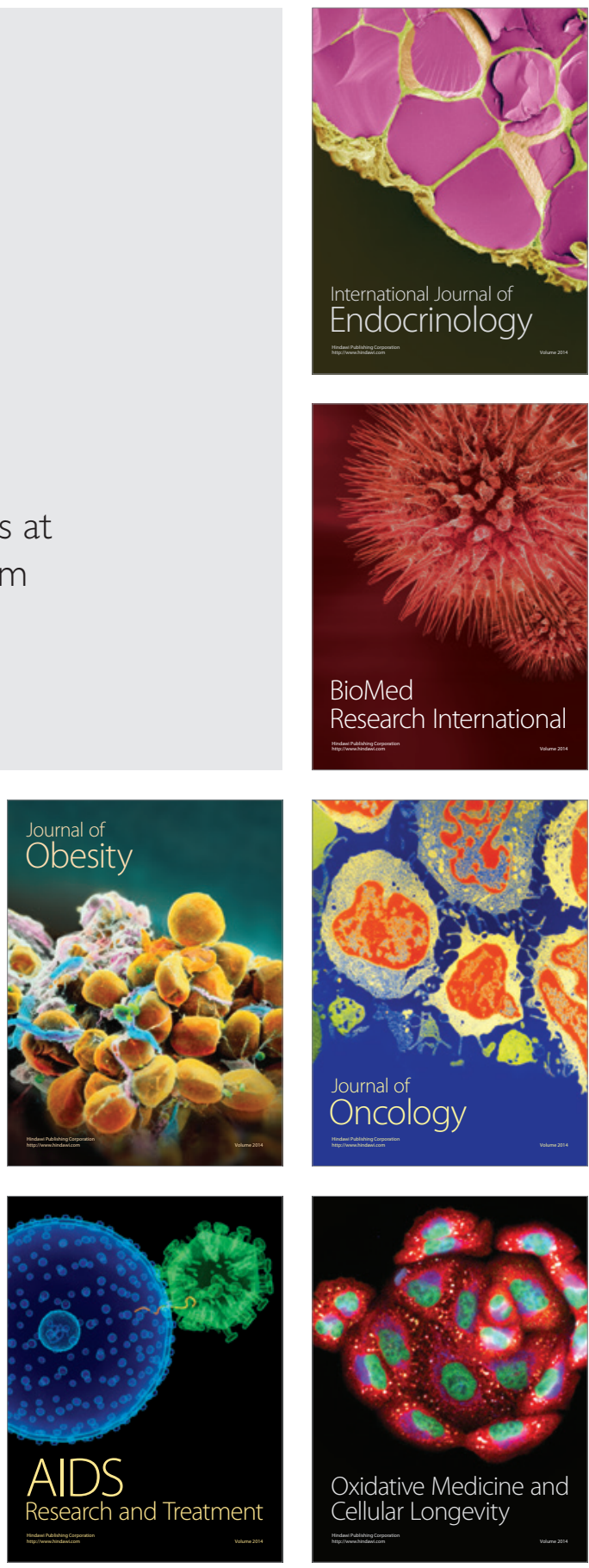